\title{
Deposition of yttria-stabilized zirconia buffer layer on Si and its suitability for $\mathrm{Y}-\mathrm{Ba}-\mathrm{Cu}-\mathrm{O}$ thin films
}

\author{
V R KATTI, S K GUPTA, A K DEBNATH, N C JAYDEVEN ${ }^{1}$, \\ L C GUPTA $^{2}$ and M K GUPTA* \\ Technical Physics and Prototype Engineering Division, ${ }^{1}$ Fuel Chemistry Division, Bhabha \\ Atomic Research Centre, Trombay, Bombay 400085, India \\ ${ }^{2}$ Tata Institute of Fundamental Research, Colaba, Bombay 400005, India
}

\begin{abstract}
The deposition of yttria-stabilized zirconia (YSZ) as buffer layer on (100) silicon has been studied by rf sputtering with a view to subsequently preparing superconducting films of $\mathrm{YBa}_{2} \mathrm{Cu}_{3} \mathrm{O}_{x}$ on it. As-deposited films were found to be (100) oriented. The thermal mismatch and reaction between $\mathrm{Si}$ and $\mathrm{YSZ}$ at high temperatures were found to give rise to cracks in the films. Grain growth of buffer layer on annealing helped in the formation of superconducting phase.
\end{abstract}

Keywords. YSZ buffer layer; thin films; high temperature superconductıvity; silicon.

\section{Introduction}

Deposition of $\mathrm{Y}-\mathrm{Ba}-\mathrm{Cu}-\mathrm{O}$ on silicon is of technological importance. Though direct deposition of $\mathrm{Y}-\mathrm{Ba}-\mathrm{Cu}-\mathrm{O}$ in $\mathrm{Si}$ has been tried, the quality of the film produced is quite poor (Berberich et al 1988). This is presumably due to (i) reaction between film and substrate and (ii) the mismatch between the thermal and lattice parameters. Intermediate buffer layers have been studied with a view to overcome these difficulties (Mogro-Campero and Turner 1988).

The present investigation was carried out with a view to studying the suitability of yttria-stabilized zirconia as a buffer layer. The presence of cracks and the formation of $\mathrm{ZrSiO}_{4}$ was observed when the buffer layers were annealed above $600^{\circ} \mathrm{C}$. Subsequently deposition of $\mathrm{Y}-\mathrm{Ba}-\mathrm{Cu}-\mathrm{O}$ on such buffer layers yielded barium-deficient films on postdeposition annealing. The loss of barium has been confirmed to be due to the formation of $\mathrm{Ba}_{2} \mathrm{SiO}_{4}$ at the elevated temperatures.

\section{Experimental}

Thin film deposition of both $\mathrm{YSZ}$ buffer layer and $\mathrm{Y}-\mathrm{Ba}-\mathrm{Cu}-\mathrm{O}$ was carried out by rf sputtering. A $40 \mathrm{~mm}$ diameter target of nominal composition $\mathrm{Y}_{0.1} \mathrm{Zr}_{0.9} \mathrm{O}_{x}$ was used for buffer layer deposition. Sputtering was carried out at 0.05 torr argon pressure. Films of about one micron thickness were deposited on (100) oriented silicon. Subsequently they were annealed for $4 \mathrm{~h}$ at various temperatures between $600^{\circ} \mathrm{C}$ and $1100^{\circ} \mathrm{C}$. A uniform heating and cooling rate of $100^{\circ} \mathrm{C} / \mathrm{h}$ was used.

Thin film deposition of $\mathrm{Y}-\mathrm{Ba}-\mathrm{Cu}-\mathrm{O}$ on buffered silicon substrates was carried out using a stoichiometric target. Other deposition conditions were essentially the same as in

\footnotetext{
* To whom correspondence should be addressed.
} 
the case of $\mathrm{YSZ}$. $\mathrm{Y}-\mathrm{Ba}-\mathrm{Cu}-\mathrm{O}$ films were post-annealed under oxygen for $30 \mathrm{~min}$ at various temperatures in the range $830-890^{\circ} \mathrm{C}$.

\section{Results}

Both $\mathrm{YSZ}$ and $\mathrm{Y}-\mathrm{Ba}-\mathrm{Cu}-\mathrm{O}$ films were investigated for the phase and microstructure. In addition resistivity was measured on $\mathrm{Y}-\mathrm{Ba}-\mathrm{Cu}-\mathrm{O}$ films.

\subsection{YSZ films}

X-ray diffraction of the as-deposited YSZ film shown in figure 1 clearly reveals its highly oriented (100) nature. Similar result has been reported by Morita et al (1985) for zirconia deposition using electron beam evaporation. Weak (311) reflection is also present. Annealing of films between 600 and $975^{\circ} \mathrm{C}$ reduces the width and increases the

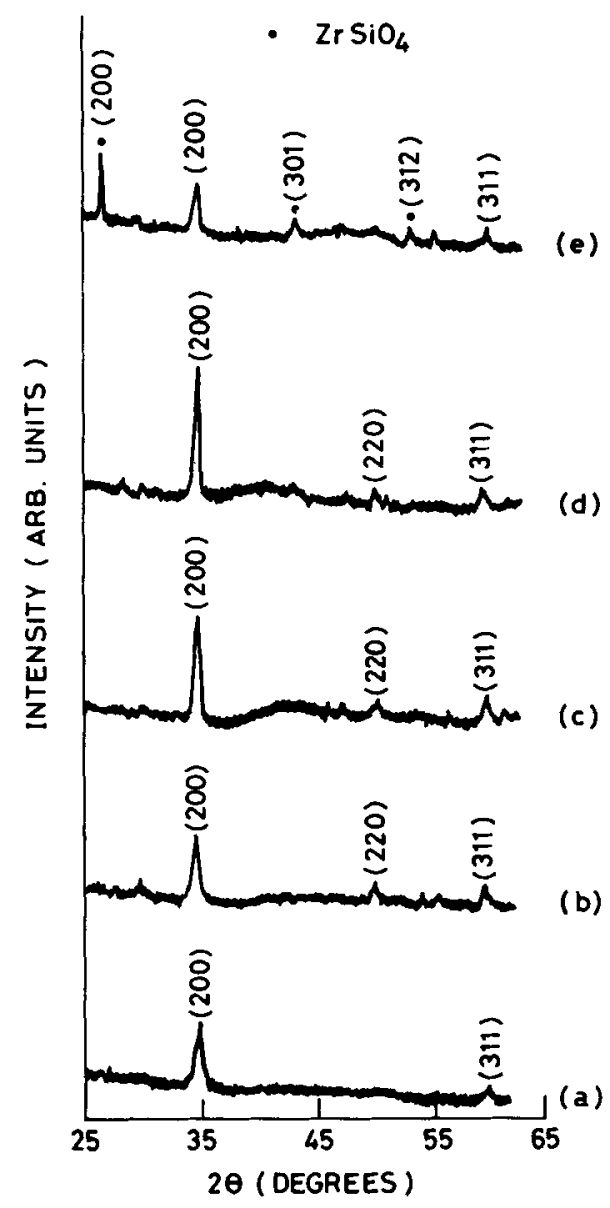

Figure 1. X-ray diffraction pattern for YSZ buffer layer on silicon (a) as-deposited and annealed at (b) $600^{\circ} \mathrm{C}$ (c) $800^{\circ} \mathrm{C}$ (d) $975^{\circ} \mathrm{C}$ and (e) $1100^{\circ} \mathrm{C}$. 

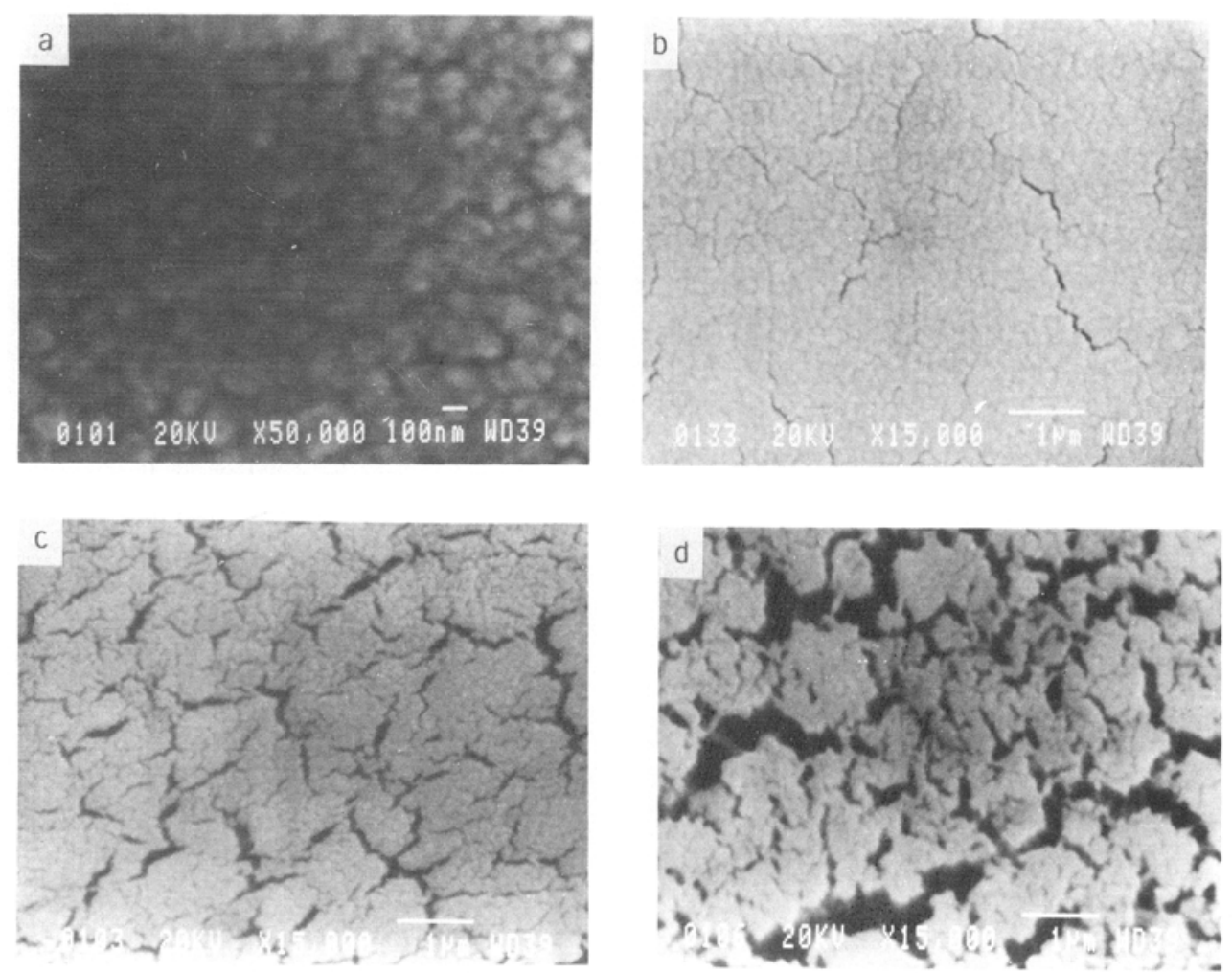

Figure 2. Scanning electron micrographs of YSZ buffer layer on silicon (a) as-deposited and annealed at (h) $600^{\circ} \mathrm{C}$ (c) $975^{\circ} \mathrm{C}$ (d) $1100^{\circ} \mathrm{C}$.

height of (200) peak indicating grain growth. Small peak corresponding to $(220)$ is also seen on annealing. In contrast to our observations YSZ films earlier reported by Lee et al (1988) by sputtering were randomly oriented. In YSZ films annealed at $1100^{\circ} \mathrm{C}$, the height of (200) reflection is seen to have reduced. Reflections corresponding to $\mathrm{ZrSiO}_{4}$ are also seen. This suggests that at high temperatures YSZ reacts with silicon to yield $\mathrm{ZrSiO}_{4}$.

SEM photographs obtained for as-deposited and annealed films are shown in figure 2. The micrographs clearly show the grain growth on annealing as also revealed by the XRD data. Further on annealing films are seen to develop cracks. We attribute this to the enhanced reaction between silicon and YSZ at high temperature and also to the thermal mismatch. Although XRD data show reaction only in films annealed at $1100^{\circ} \mathrm{C}, \mathrm{SEM}$ in figure 2 suggest the onset of reaction even at much lower temperatures. This is further supported by the observation that films turned from transparent to whitish on annealing above $800 \mathrm{C}$.

\section{$3.2 \quad Y-B a-C u-O$ films}

YSZ films annealed at $975 \mathrm{C}$ which showed sharp (200) peak and good grain growth were used for depositing $\mathrm{Y}-\mathrm{Ba}-\mathrm{Cu}-\mathrm{O}$ films during our initial trials. The composition of the asdeposited film was close to $\mathrm{YBa}_{1.75} \mathrm{Cu}_{3.1} \mathrm{O}_{x}$. On subsequent annealing loss of barium 


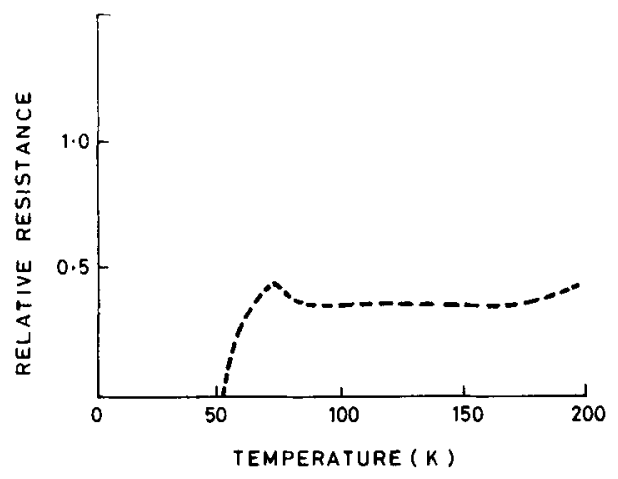

Figure 3. Resistance vs temperature plot for a typical $\mathrm{Y}-\mathrm{Ba}-\mathrm{Cu}-\mathrm{O}$ film on silicon with $\mathrm{YSZ}$ buffer layer.

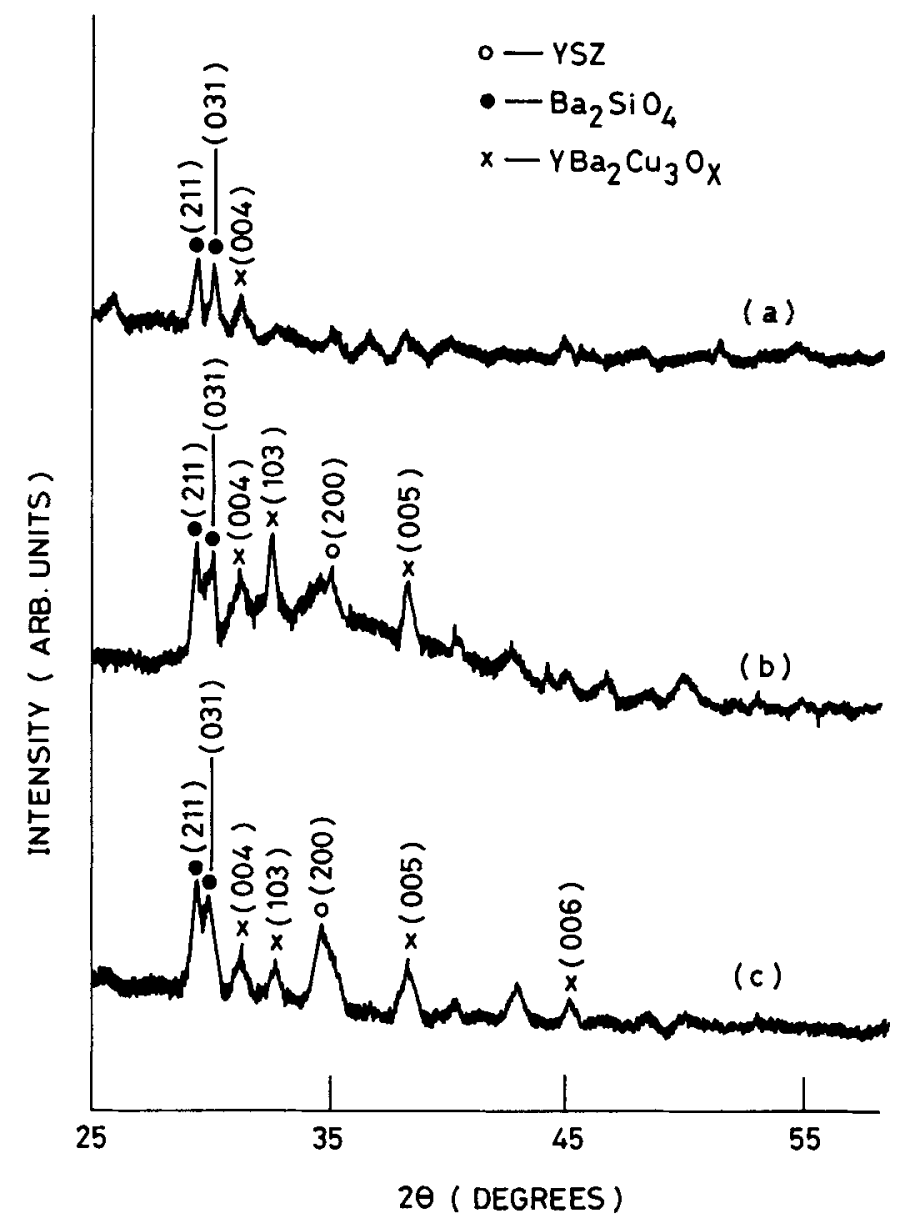

Figure 4. X-ray diffraction pattern for $\mathrm{Y}-\mathrm{Ba}-\mathrm{Cu}-\mathrm{O}$ film deposited on (a) silicon (b) unannealed buffer layer and (c) $975^{\circ} \mathrm{C}$ annealed buffer layer. 
from the film was observed. Room temperature resistance of films annealed between 830 and $890^{\circ} \mathrm{C}$ was measured and those annealed between 845 and $860^{\circ} \mathrm{C}$ were found to have minimum value. $R$ vs Tcurve for a film annealed at $845 \mathrm{C}$ is reproduced in figure 3 . Transition to superconducting state $(R=0)$ is seen to occur at $52 \mathrm{~K}$ in this case.

In order to investigate the loss of barium on annealing, $\mathrm{XRD}$ of the $\mathrm{Y}-\mathrm{Ba}-\mathrm{Cu}-\mathrm{O}$ film deposited on bare silicon as well as with buffer layer was studied. The plots are shown in figure 4. It is seen from figure $4 \mathrm{a}$ that $\mathrm{Si}$ reacts with $\mathrm{Y}-\mathrm{Ba}-\mathrm{Cu}-\mathrm{O}$ to yield $\mathrm{Ba}_{2} \mathrm{SiO}_{4}$. The formation of $\mathrm{Ba}_{2} \mathrm{SiO}_{4}$ was also confirmed in this case when silicon with YSZ layer was used (figure $4 \mathrm{c}$ ). This is presumably due to crack formation in the film through which $\mathrm{Y}-\mathrm{Ba}-\mathrm{Cu}-\mathrm{O}$ reacts with $\mathrm{Si}$. This also explains the observation made by Greve et al (1989). As a consequence $\mathrm{Y}-\mathrm{Ba}-\mathrm{Cu}-\mathrm{O}$ films on Si with YSZ buffer layer should be annealed at much lower temperatures compared to those for YSZ substrate as reported by Aswal et al (1989). However in low temperature-annealed buffer layer the crystallite size is very small. The large number of grain boundaries yield poor quality $\mathrm{Y}-\mathrm{Ba}-\mathrm{Cu}-\mathrm{O}$ films (figure $4 \mathrm{~b}$ ). High temperature annealing on the other hand though yields large size YSZ crystallites, it also leads to the formation of cracks through which $\mathrm{Y}-\mathrm{Ba}-\mathrm{Cu}-\mathrm{O}$ film reacts with $\mathrm{Si}$. Therefore in our opinion the deposition of YSZ buffer layer at room temperature cannot yield good quality film and the YSZ layer should also be formed in situ at high temperature.

\section{Conclusion}

The YSZ film deposited on Si when subjected to high temperature anneal develops cracks. The formation of $\mathrm{ZrSiO}_{4}$ and thermal mismatch are found to be responsible for this. In $\mathrm{Y}-\mathrm{Ba}-\mathrm{Cu}-\mathrm{O}$ films deposited on $\mathrm{YSZ}$ buffered Si substrate the loss of barium observed on annealing is attributed to the reaction between film and the substrate.

\section{Acknowledgement}

Authors are thankful to Shri S C Purandare for help in EDX and SEM analysis.

\section{References}

Aswal D K, Muthe K P, Karandikar S C, Mirza T, Gupta S K, Sabharwal S C, Gupta M K, Gupta L C and Vijayraghavan R 1989 Phase Transitions 19127

Berberich P, Tate J, Dietsche W and Kinder H 1988 Appl. Phys. Lett. 53925

Greve D W, Stamper A K, Schlesinger T E and Migliuolo M 1989 Mater. Sci. Engg. A109 325

Lee J W, Schlesinger T E, Stamper A K, Migliuolo M, Greve D W and Laughlin D E 1988 J. Appl. Phys. 64 6502

Mogro-Campero A and Turner L G 1988 Appl. Phys. Lett. 521185

Morita M. Fukumoto H. Imura T. Oraka Y and Ichihara M 1985 J. Appl. Phys. 582407 